\title{
Effect of Online and Offline Voice Therapy Programs in Patients with Hyperfunctional Voice Disorder: A Case Study
}

\author{
Ha-Na Lee ${ }^{a}$, Jae-Yeon Yoo ${ }^{b}$, Jun-Hee Park ${ }^{c}$ \\ ${ }^{a}$ Voice Clinic, Department of Otolaryngology, Chosun University Hospital, Gwangju, Korea \\ ${ }^{b}$ Department of Speech Language Pathology, Honam Univerisity, Gwangju, Korea \\ 'Department of Otolaryngology-Head and Neck Surgery, Chosun University School of Medicine, Gwangju, Korea
}

Correspondence: Jun-Hee Park, PhD Department of Otolaryngology-Head and Neck Surgery, Chosun University School of Medicine, 365 Pilmun-daero, Dong-gu, Gwangju 61453, Korea

Tel: +82-62-220-3200

Fax: +82-62-225-2702

E-mail: entjh28@hanmail.net

Received: July 20, 2019

Revised: August 23, 2019

Accepted: August 28, 2019
Objectives: Voice therapy aims to produce better voice quality by changing voice behavior. Patients are required to constantly practice and change their behavior every day. Voice therapy using smart phones not only encourages voice training in daily life, but also provides objective data during training. We investigated whether online and offline voice therapy programs using smartphones are effective for improvement of voice disorders. Methods: The present study was conducted on five patients with hyperfunctional voice disorder. Voice therapy was performed using vocal aerobic treatment (VAT). Offline VAT was performed once a week, and online VAT was performed more than once a week. Voice evaluations were achieved via acoustic evaluation, aerodynamic evaluation, and subjective voice evaluation before and after therapy. Results: The acoustic evaluation results showed that the Jitter, Shimmer and NHR decreased after therapy, while frequency range $(\mathrm{Hz})$ and semitone increased. Aerodynamic evaluation illustrated increased expiratory volume (FVC), maximum phonation time (PHOT) and improved respiratory function related to phonation. Subjective voice evaluation demonstrated that the degree of voice disorder was reduced compared to that before the therapy. Conclusion: The online and offline voice therapy programs were found to be effective in improving the FO and voice quality of voice disorder patients as well as respiratory function related to phonation, and also in increasing the FO range. In future studies, it is necessary to study the efficacy of online and offline voice therapy programs in a wide range of patients. Also, online program development and application of voice therapy techniques used in evidence-based clinical studies are suggested to be actively conducted.

Keywords: Home voice trainer, Online voice therapy, Vocal aerobic treatment, Voice therapy, Voice disorder
음성은 호흡, 발성, 공명 등의 음성산출기관의 협응의 과정을 거 쳐 시작되는 것으로 이러한 음성산출 과정에 문제가 발생할 경우 음성 문제가 나타나게 된다. 음성 문제가 지속적으로 발생할 경우 후두의 구조적·기능적 변화가 나타나게 되고 이는 음성장애로 이 어진다. 음성장애의 치료는 원인에 따라 약물적 치료, 수술적 치료, 음성치료 등의 치료방법을 적용하게 된다. 음성치료는 음성위생교 육, 호흡훈련, 발성방법의 변경 등을 통해 환자의 음성산출방법을
변화시키는 것이다. 이러한 음성산출방법의 변화는 환자의 행동 변 화를 요구하는 것으로 환자 스스로 음성 문제를 인식하고 이를 일 상생활에 적용하는 것이 매우 중요하다.

그러나 음성장애를 경험하는 환자의 경우 음성치료 종결 시 만 족도는 $84.3 \%$ 로 높았지만, 음성치료 권고 시 환자는 음성치료에 대 한 신뢰도와 인식이 낮은 편이었다(Ahn, Shin, \& Shin, 2016). 또한 Choi (2013)의 연구에서 음성언어재활사에게 음성치료 중단비율 
에 대해 조사한 결과 '자주' 중단한다라고 응답한 음성언어재활사 의 비율이 29 명 중 21 명(72\%)으로 높은 비중을 차지하였으며, 음성 언어재활사에게 필요한 직무 능력으로 정확한 음성치료기법에 대 한 이해와 적용이 필요하며, 환자에게 음성치료의 필요성을 인식시 키는 것이 중요하다고 보고하였다. 이러한 문제점을 바탕으로 언어 치료분야에서는 효과적인 치료를 위해 다양한 치료방법론에 대해 연구가 진행되어 왔으며, 컴퓨터 기술과 멀티미디어 기술 등과 같은 기술 매체들의 구체적인 치료효과에 대한 검증 필요성이 높아지고 있다(Bae, Park, Kim, \& Kwon, 2014). 최근 음성치료 분야에서는 음성평가 시 사용되는 음성분석장비(Computerized Speech Lap) 이외에도 스마트폰과 다양한 디지털 매체를 활용한 음성평가 및 음성치료에 관한 연구가 진행되고 있었다. Lee, Lee와 Choi (2018) 의 연구에서는 스마트폰이 장애음성을 선별하는 데 음향학적 음 성 평가도구로 유용한지 알아보았으며, 연구 결과 선별도구로서 유 용성이 있는 것으로 보고하였다. Lee, Park과 Yoo (2019)의 연구에 서는 국내 음성치료 관련 모바일 콘텐츠 분석과 전문가 및 사용자 수요조사를 통해 스마트폰기반 음성치료 프로그램을 개발하는 연 구가 있었다(Lee et al., 2019). 또한 스마트폰을 활용한 성대결절 환 자를 대상으로 음성훈련 및 음질평가를 위한 애플리케이션 개발 에 관한 연구가 보고되고 있었다(Kim, 2018). 또한 Park, Kim, Lee, $\mathrm{Bae}$ 와 Kwon (2019)의 연구에서는 기존 실시간 음도 피드백과 강도 피드백을 증강현실기반 음성치료 소프트웨어로 개발하여 아동을 대상으로 적용한 연구가 있었다. Lee 등(2019)의 연구에서는 음성 장애환자에게 스마트폰기반 음성치료 프로그램에 대한 사용자 만 족도 설문 평가를 실시한 결과 애플리케이션에서 제공되는 음성치 료 프로그램의 난이도, 내용에 대체로 만족하는 것으로 보고하였 으며, 이러한 스마트폰을 사용한 가정용 음성치료 프로그램의 개 발 필요성에 관련된 항목에서 “매우 필요하다."에 응답한 비율이 많았다. 또한 향후 스마트폰을 사용한 가정용 음성치료 프로그램 의 사용 여부를 묻는 항목에서 “매우 사용할 의향이 있다."에 응답 한 비율이 많았다. 따라서 이러한 디지털 매체들을 활용한 음성치 료 프로그램을 실제 음성장애 환자에게 적용한다면 음성치료 중도 탈락률과 치료의 참여도를 높일 수 있을 것이라고 기대된다.

이미 국외연구에서는 애플리케이션, 웹 기반 프로그램과 같은 디 지털 매체를 활용한 음성치료의 효과성에 대해 보고되고 있었다. Grillo (2017)의 연구에서는 예비교사를 대상으로 Global Voice Prevention Model (GVPM)의 대면 실습과 전화 실습의 두 가지 방 법의 효과를 알아보고자 애플리케이션(VoiceEvalU8)을 활용하여 음성평가를 실시하였다. 실험군은 4 주간 보컬교육과 음성위생교 육, 3 주간 보컬 트레이닝을 실시하였고 통제군은 1 주간 보컬교육과
음성위생교육만 실시하여 치료 전후 음성평가를 실시하였다. 연구 결과 실험군에서 음향학적으로 유의한 개선이 나타났다고 보고하 였다. Tindall, Huebner, Stemple과 Kleinert (2008)은 파킨슨병 환 자 24명을 대상으로 비디오폰을 사용한 자가 음성훈련 프로그램 Lee Silverman Voice Treatment (LSVT)를 실시한 결과, 치료 후 모 음 발성, 읽기 문단, 독백 등에서 음압 수준(sound pressure level, $\mathrm{SPL})$ 의 유의한 증가를 보고하였으며 환자의 만족도가 높았다고 보 고하였다. Fu, Theodoros와 Ward (2015)의 연구에서는 성대결절 환자 10 명을 대상으로 Skype를 활용하여 음성위생교육을 포함한 3 주 동안 8회기의 음성치료 프로그램을 실시하여 음성개선에 효과 적인지 알아보았다. 연구 결과, 치료 후 공기역학적 음성평가, 음향 학적 음성평가, GRBAS 척도, 음성장애지수에서 유의한 개선이 나 타났다고 보고하였다. 또한 파킨슨병 환자 3 명을 대상으로 웹 기반 LSVT 프로그램을 실시한 결과, 모음, 문단 읽기, 독백 등의 과제에 서 음압 수준(SPL)의 개선이 나타났으며 이러한 결과는 대면치료 를 받은 환자와 동일한 수준의 음성개선을 보였다고 보고하였다 (Howell, Tripoliti, \& Pring, 2009).

또한 음성장애 분야에서 다양한 디지털 매체들을 활용한 원격 치료(telepractice)와 기존 대면 음성치료와 효과를 비교하는 연구 들이 있었다. 연구 결과, 기존 대면 음성치료뿐만 아니라 원격치료 도 음성개선에 효과적이라고 보고하였다(Cole et al., 2007; Mashima et al., 2003; Rangarathnam et al., 2015).

이처럼 국외연구에서 다양한 디지털 매체를 활용한 음성치료 프 로그램 개발 및 효과에 대한 다양한 연구가 진행되고 있었다. 반면 국내 음성장애 분야에서는 장애음성 선별평가, 음성치료 애플리케 이션 개발 등의 연구가 있었으나 이를 활용한 음성치료의 효과성에 대해 알아본 연구가 거의 없었다. 또한 Lee 등(2019)에서 국내 음성 치료 관련 애플리케이션을 분석한 결과, 실질적으로 음성치료를 위 한 애플리케이션은 부족한 실정이었다.

스마트폰은 장소와 시간에 제약 없이 일상생활에서 가장 밀접하 게 사용되고 있는 기기로, 스마트폰을 활용한 애플리케이션 기반 음성치료 프로그램은 자가 음성훈련을 독려하기 위한 적절한 매체 라고 할 수 있다. 본 연구에서는 스마트폰 기반 애플리케이션을 활 용한 온라인 음성치료와 병원에서 실시하는 오프라인 음성치료로 구성된 성대에어로빅치료(vocal aerobic treatment, VAT)를 실시하 였다. 모든 환자는 치료실에서 오프라인 VAT 음성치료를 실시하였 고 가정에서는 자가 음성훈련 프로그램인 온라인 VAT 프로그램을 활용하여 환자 스스로 음성훈련을 실시하는 것으로 진행되었다.

따라서 본 연구에서는 온·오프라인 음성치료 프로그램이 음성 장애 환자의 음성개선에 미치는 효과에 대해 알아보고자 하였다. 
Ha-Na Lee, et al. • Effect of Online and Offline Voice Therapy Programs in Hyperfunctional Voice Disorder

연구 문제는 다음과 같았다.

첫째, 온·오프라인 음성치료 프로그램은 음성장애인의 음향학적 평가 매개변수(F0, jitter, shimmer, NHR) 변화에 영향을 주는가?

둘째, 온·오프라인 음성치료 프로그램은 음성장애인의 공기역 학적 평가 매개변수(FVC, MEAF, PHOT, MPAP) 변화에 영향을 주는가?

셋째, 온·오프라인 음성치료 프로그램은 음성장애인의 주관적 음성만족도 변화에 영향을 주는가?

\section{연구방법}

\section{연구대상}

2018년 5월부터 11월까지 본원에 내원한 환자 중 이비인후과 전 문의 1 명에 후두스트로스코피상 과기능적 음성장애로 진단된 성 인 5명(남성 2명, 여성 3명)을 대상으로 하였다. 구체적인 환자 선정 기준은 만 19 세 이상 성인 환자, 성대 접촉 문제로 인해 음성 문제를 가지고 있는 환자, 시각 및 청각 문제가 없으며 애플리케이션을 작 동하는 데 어려움이 없는 환자, 이전에 음성치료를 받은 경험이 없 는 환자, 질병으로 인해 장기간 약물을 복용하지 않았으며 현재 복 용 중이지 않은 환자를 선정하였다. 환자의 일반적인 정보는 Table 1 과 같았다.

\section{연구절차}

연구기간은 2018년 5월부터 11월까지이며 오프라인 치료는 주 1 회, 온라인 치료는 주 1 회 이상 실시하도록 하였다. 환자별로 오프 라인 치료는 총 6-10회기, 온라인 치료는 총 6-11회기 실시하였다. 오프라인 치료는 주 1 회, 40 분 병원에서 실시하였고, 온라인 치료 는주 1 회 이상 가정에서 30 분 실시하였다.

\section{평가도구}

\section{음향학적 평가}

환자의 음도, 음질, 음역을 객관적으로 평가하기 위해 Computerized Speech Lab (CSL; Model 4150B, KayPentax)의 Multi-Dimen-

Table 1. Participants' characteristics

\begin{tabular}{lccccc}
\hline Subject & Gender & Age (yr) & Job & Diagnosis & Onset \\
\hline A & Female & 26 & Teacher & Vocal nodule & 3 months \\
B & Female & 46 & Office worker & Vocal nodule & 3 months \\
C & Female & 49 & Professor & Vocal nodule & 6 months \\
D & Male & 22 & Student & Mutational falsetto & 7 years \\
E & Male & 29 & Telemarketer & Vocal polyp & 6 months \\
\hline
\end{tabular}

sional Voice Program (MDVP; Model 4150B, KayPentax)과 Voice Range Profile (VRP; Model 4150B, KayPentax)을 사용하여 측정 하였다.

MDVP를 통해 기본주파수(F0), 주파수변동률(jitter), 진폭변동 률(shimmer), 소음대배음비(noise-to-harmonic ratio, NHR) 값을 측정하였다. 검사방법은 마이크로폰과 $15 \mathrm{~cm}$ 거리를 두고 $/ \mathrm{a} /$ 를 평 상시와 동일한 음도와 강도로 3 초간 연장발성하도록 하였다.

$\mathrm{VRP}$ 는 환자의 음역을 평가하기 위해 실시하였으며 주파수 범위 (F0 range)와 반음(semitone)의 개수를 측정하였다. 평가를 실시하 기 전 환자에게 모델링을 1 회 제공하였다. VRP는 환자에게 모음 $/ \mathrm{a} /$ 를 가장 낮은 음부터 높은 음까지 반음씩 올리면서 산출하도록 지시하였고, 이후 반음씩 내려가며 가장 낮은 음도까지 산출하도 록 지시하였다. 이를 3 회 실시하여 측정하였다.

\section{공기역학적 평가}

환자의 전반적인 호흡기능과 발성 시 공기의 효율성을 알아보고 자 Phonatory Aerodynamic System (PAS; Model 6600, KayPentax) 을 사용하였다.

PAS에서는 폐활량 과제, 최대연장발성 과제, 음성효율 과제를 실 시하여 호기량(expiratory volume, FVC), 평균호기류율(mean expiratory airflow, MEAF), 최대연장발성시간(maximum phonation time, $\mathrm{PHOT}$ ), 평균성문하압(mean air pressure, $\mathrm{MPAP}$ )값을 측정 하였다.

폐활량 과제는 환자가 마스크를 얼굴에 밀착시킨 후 공기를 최대 한 들이마시고 최대한 내쉬도록 지도하였다. 최대연장발성 과제에 서는 환자에게 마스크를 얼굴에 밀착시키고 공기를 최대한 들이마 신 후 편안한 음도와 강도로 /a/를 최대한 길게 연장발성하도록 지 시하였다. 이를 3 회 반복시켰으며 그중 가장 길게 실시한 것을 기록 하였다. 음성효율성 과제는 마스크에 튜브를 장착시킨 후 마스크를 얼굴에 밀착시키고 튜브를 입술과 윗니 사이에 위치시킨다. 이후 편 안한 음도와 강도로 $/ \mathrm{pa}$ 를 초당 $1.5-2$ 음절의 속도로 5 회 반복하도 록 하였다. 성문하압은 첫음절과 끝음절을 제외한 중간 3 회의 평균 값을 분석하였다.

\section{주관적 음성평가}

주관적 음성평가는 GRBAS 평가와 음성장애지수(Voice Handicap Index, VHI)를 통해 평가하였다.

\section{GRBAS 평가}

GRBAS 평가는 환자의 음성을 듣고 치료사가 청지각적으로 평 
가하는 주관적인 평가로 $\mathrm{G}$ (grade)는 전체적인 목쉰 소리, $\mathrm{R}$ 은 거 친 음성(rough), $\mathrm{B}$ 는 기식 음성(breathy), $\mathrm{A}$ 는 무력한 음성(asthenic), $\mathrm{S}$ 는 쥐어짜는 음성(strain)을 의미한다. 각 영역별로 4점 척도로 구성되어 있으며 0점은 정상 음성, 3점은 가장 나쁜 음질을 의미한 다. GRBAS 평가는 20 년 경력을 가진 1 급 언어재활사가 환자의 치 료 전후 연장발성 /a/를 듣고 평가하였다.

\section{음성장애지수}

치료 전후 환자가 느끼는 주관적 음성 만족도를 평가하기 위한 실 시하였다. 평가도구는 한국어판 음성장애지수(Korean-Voice Handicap Index, K-VHI; Yun, Kim, Son, \& Choi, 2008)를 사용하였 다. 음성장애지수는 기능적, 신체적, 정서적 영역으로 구성되어 있으 며 총 30 문항으로 5점 척도로 평가할 수 있다. 총 점수는 0점부터 120 점까지로 총 점수가 높을수록 목소리로 인해 일상생활에서 불 편함을 겪는 정도가 높다고 평가된다. 음성장애지수에서는 기능적, 신체적, 정서적 각 하위영역의 점수와총 점수의 변화를 측정하였다.

\section{음성치료 프로그램}

음성치료는 총체적 음성치료에 기반을 둔 성대에어로빅치료 프 로그램을 실시하였다. 성대에어로빅치료 프로그램은 이완, 호흡, 발 성 그리고 발화까지 음성산출 전반에 대한 음성치료법이다(Yoo \& Lee, 2018). 음성치료 프로그램은 이완단계, 호흡단계, 발성단계, 발 화단계 순서로 진행하였으며, 각 단계별 훈련 시작 회기는 환자의
수행수준에 따라 진행하였다. 또한 단계별 수행 수준이 일정한 기 준에 도달한 후에 다음 단계를 실시하였다. 오프라인 음성치료 프 로그램의 절차와 준거는 Table 2와 같았다.

음성치료 활동은 환자가 주 1 회 병원에 내원하여 실시하는 오프 라인 치료활동과 환자가 가정에서 주 1 회 이상 스스로 애플리케이 션을 사용하는 온라인 치료활동으로 구성하였다. 온라인 음성치 료 프로그램은 오프라인에서 실시한 성대에어로빅치료 프로그램 을 수정하여 스마트폰 애플리케이션(홈 보이스 트레이너)으로 개

Table 3. On-line and off-line voice therapy program

\begin{tabular}{|c|c|c|}
\hline Phase & On-line (at home) & Off-line (at hospital) \\
\hline \multirow[t]{2}{*}{ Consulting } & Survey for voice problem & Vocal hygiene \\
\hline & & Check for home voice training \\
\hline \multirow[t]{2}{*}{ Relaxation } & Stretching of body & Stretching of body \\
\hline & Laryngeal massage & Laryngeal massage \\
\hline \multirow[t]{3}{*}{ Breathing } & Abdominal breathing exercise & Abdominal breathing \\
\hline & Inspiration exercise & $\begin{array}{l}\text { Expiration exercise with straw \& } \\
\text { water }\end{array}$ \\
\hline & Expiration exercise & Breathing accent exercise \\
\hline \multirow[t]{3}{*}{ Phonation } & Pitch \& loudness exercise & $\begin{array}{l}\text { Maximum sustained phonation } \\
\text { exercise }\end{array}$ \\
\hline & Gliding exercise & Pitch exercise \\
\hline & & Loudness exercise \\
\hline \multirow[t]{3}{*}{ Speaking } & Speaking with optimal pitch & Speaking exercise with word \\
\hline & Speaking with loudness & Speaking exercise with sentence \\
\hline & $\begin{array}{l}\text { Speaking with speech rate, } \\
\text { pauses }\end{array}$ & Speaking exercise with paragraph \\
\hline
\end{tabular}

Table 2. Process of vocal aerobic treatment program

\begin{tabular}{|c|c|c|}
\hline Phase & Contents & Criteria \\
\hline \multirow[t]{2}{*}{ Relaxation } & Stretching of body & The performance level is evaluated as 0 to 5 points. \\
\hline & Laryngeal massage & If the score 4 or more, perform the next phase. \\
\hline \multirow[t]{5}{*}{ Breathing } & Abdominal breathing: supine, sitting, upright position & Maximum sustained expiration time: 20 seconds or more \\
\hline & Expiration exercise with tube in water: maximum sustained expiration exercise & The contraction of the abdomen changes according to the accent \\
\hline & Breathing accent exercise: & The performance level is evaluated as 0 to 5 points. \\
\hline & - Consonant/S/ & If the score 4 or more, perform the next phase. \\
\hline & - Straw and water & \\
\hline \multirow[t]{6}{*}{ Phonation } & Maximum sustained phonation exercise: with straw and water, with straw, with vowel & Maximum sustained phonation time: 20 seconds or more \\
\hline & Pitch exercise: & The contraction of the abdomen changes according to the accent \\
\hline & - low pitch $\rightarrow$ high pitch & The performance level is evaluated as 0 to 5 points. \\
\hline & - high pitch $\rightarrow$ low pitch & If the score 4 or more, perform the next phase. \\
\hline & - low pitch $\rightarrow$ high $\rightarrow$ low & \\
\hline & Loudness exercise: strong loudness, soft loudness & \\
\hline \multirow[t]{5}{*}{ Speaking } & Speaking exercise with word: syllable units, spacing units, one word units & The performance level is evaluated as 0 to 5 points. \\
\hline & Speaking exercise with sentence: & If the score 4 or more, perform the next phase. \\
\hline & - Spacing units (in sentence), e.g., noran/remon & \\
\hline & - One sentence units & \\
\hline & Speaking exercise with paragraph: speech rate, pause, intonation & \\
\hline
\end{tabular}


Ha-Na Lee, et al. • Effect of Online and Offline Voice Therapy Programs in Hyperfunctional Voice Disorder

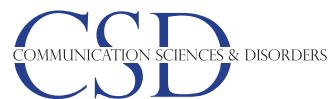

발한 프로그램을 사용하였다(Lee et al., 2019). 온·오프라인 치료활 동은 Table 3과같다.

\section{홈 보이스 트레이너}

홈 보이스 트레이너 구성

홈 보이스 트레이너는 스마트폰을 기반으로 가정에서 환자의 꾸 준한 연습 독려를 위해 개발된 애플리케이션이다(Lee et al., 2019). 홈 보이스 트레이너는 애플리케이션 소개, 개인정보, 음성훈련단 계, 음성훈련기록, 음성컨설팅 문의 등으로 구성되어 있다.

홈 보이스 트레이너 화면 예시

애플리케이션 소개 및 개인정보

애플리케이션 소개 화면에서는 홈 보이스 트레이너의 개발 목적 과 배경에 대해 설명하고 있다. 개인정보는 환자의 간단한 병력과 음성 문제에 대해 파악할 수 있도록 설문과 훈련 출석일수, 훈련 횟 수 등의 기록이 가능하다. 또한 환자의 정보는 클라우드로 연동하 여 관리할 수 있다. 화면 예시는 Figure 1과 같다.

\section{음성훈련단계(VAT)}

음성훈련단계는 기존 성대에어로빅치료의 훈련단계를 토대로 4

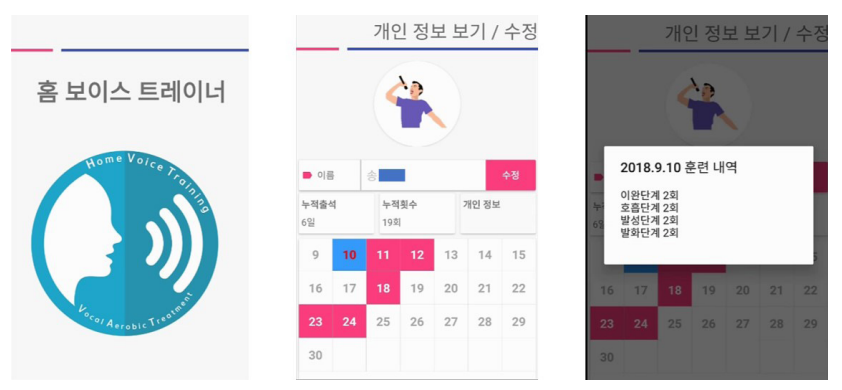

Figure 1. Main screen of home voice trainer.

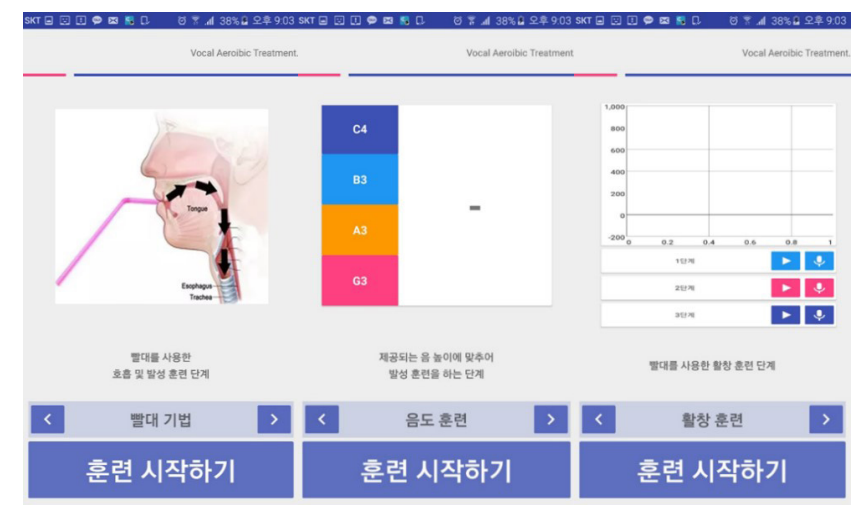

Figure 2. Example of phonation phase.
단계로 구성하였다. 훈련단계 시작 전 미리보기 단계를 추가하여 환자가 단계별로 해야 할 활동이 설명되어 있다. 훈련단계는 사진, 설 명글, 음성 및 영상 모델링을 통해 환자가 가정에서 스스로 훈련할 수 있도록구성하였다. 음성훈련 단계 화면 예는 Figure 2와같다.

\section{음성훈련기록}

음성훈련기록은 환자가 훈련단계에서 녹음한 음성을 기록하는 화면으로 환자의 음성파일은 클라우드로 연동하여 치료사가 관리 할수 있다. 음성훈련기록 화면은 Figure 3과 같다.

\section{온라인 음성컨설팅}

온라인 음성컨설팅은 환자의 기록된 음성파일을 치료사가 지속 적으로 확인하여 가정에서 연습한 음성훈련 내용을 바탕으로 실 시하였다. Figure 4 와 같이 환자의 잘못된 발성훈련을 온라인으로 컨설팅하였다. 음성컨설팅 화면은 Figure 4 와 같다.

\section{자료 처리}

온·오프라인 음성치료 프로그램 전후의 음성개선 정도를 비교 하고자 단일대상연구 설계방법을 적용하여 사전, 사후검사로 음 성 변화를 측정하였다. 사전, 중재, 사후평가에서는 음향학적 측정

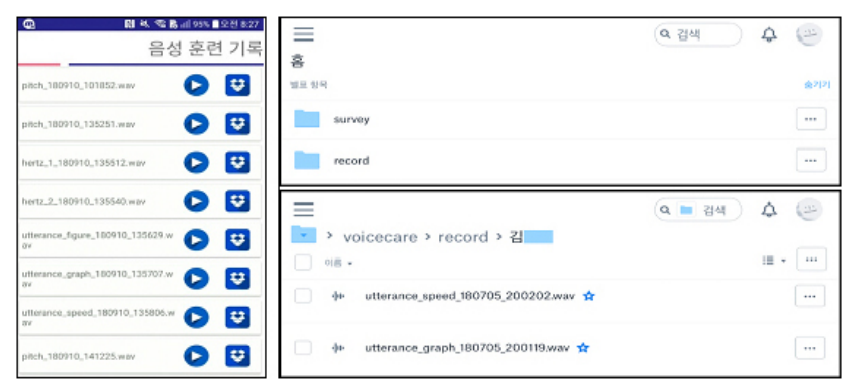

Figure 3. Example of voice training file.

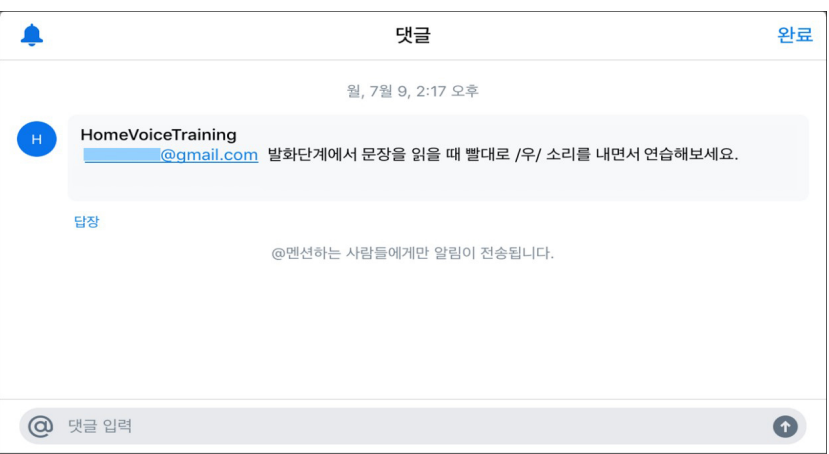

Figure 4. Example of online voice consulting. 
치(F0, jitter, shimmer, NHR, F0 range), 공기역학적 측정치(FVC, $\mathrm{PHOT}, \mathrm{MEAF}, \mathrm{MPAP})$ 의 변화를 알아보았다. 주관적 음성만족도 (VHI)와 청지각적 음성평가(GRBAS)는 사전 · 사후로 비교하였다. 사전평가와 사후평가는 1 회씩 실시하였고 중재단계에서는 2 회기 마다 객관적 음성평가를 실시하였다.

\section{연구결과}

\section{음향학적 음성 개선}

MDVP

온.오프라인 음성치료 프로그램이 음성장애 환자의 음성개선에 효과적인지 알아보고자 치료 전후에 MDVP 평가를 실시하였으며 환자별 기본주파수(F0), 주파수변동률(jitter), 진폭변동률(shimmer) 그리고 소음대배음비(NHR)의 변화를 알아보았다.

연구 결과, 환자 $\mathrm{A}, \mathrm{B}, \mathrm{E}$ 는 치료 전에 비해 음도가 증가하였으며,

Fo

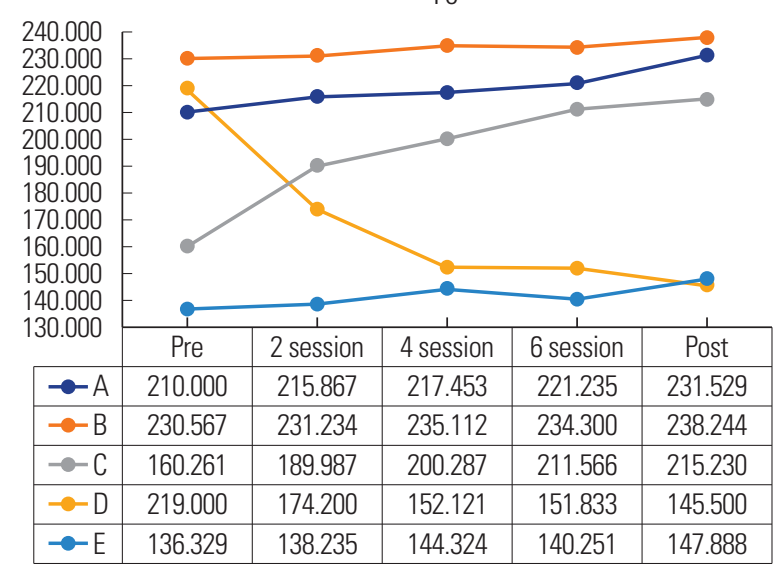

(A)

Shimmer

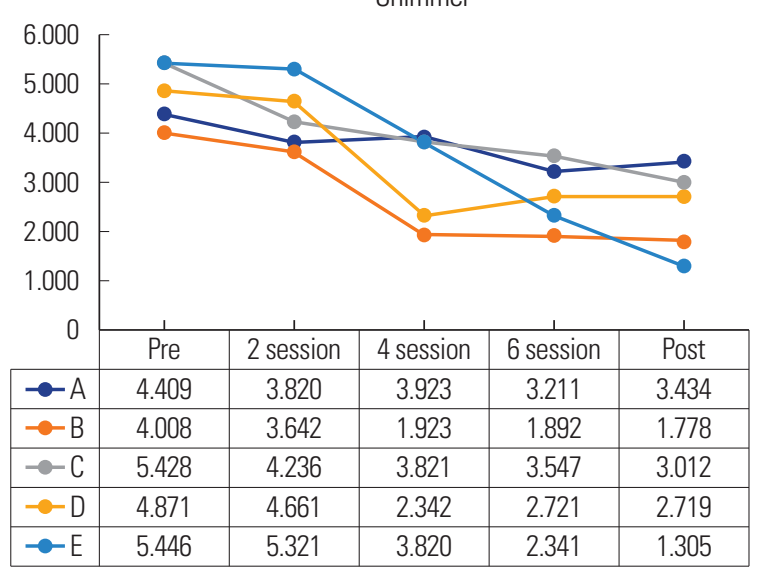

(C)
환자 C와 $\mathrm{D}$ 는 치료 전 성별에 맞지 않는 음도를 사용하였으나 치료 후 성별에 적합한 음도를 사용하였다. 또한 주파수변동률(jitter)과 진폭변동률(shimmer)는 치료 전보다 감소하였으며 정상범위에 해 당하였고, 소음대배음비(NHR)는 치료 후 모든 환자에서 정상범위 로 나타났다.

따라서 치료 전후 $\mathrm{MDVP}$ 를 각 환자별로 실시한 결과, 환자는 남 성 및 여성에 적절한 음도를 유지하였고, 음질적인 측면에서 음성 이 개선되었음을 알 수 있었다. MDVP 결과는 Figure 5와같다.

VRP

VRP 평가에서는 주파수범위(Hz), 반음(semitone) 개수의 변화 를 통해 온·오프라인기반 음성치료 프로그램 전후의 음역 향상 정 도를 알아보고자 하였다.

연구 결과, 모든 환자에서 치료 후 주파수범위 $(\mathrm{Hz})$ 가 증가하였으 며, 반음(semitone)의 개수는 동일하거나 향상하였다. 특히 환자 E

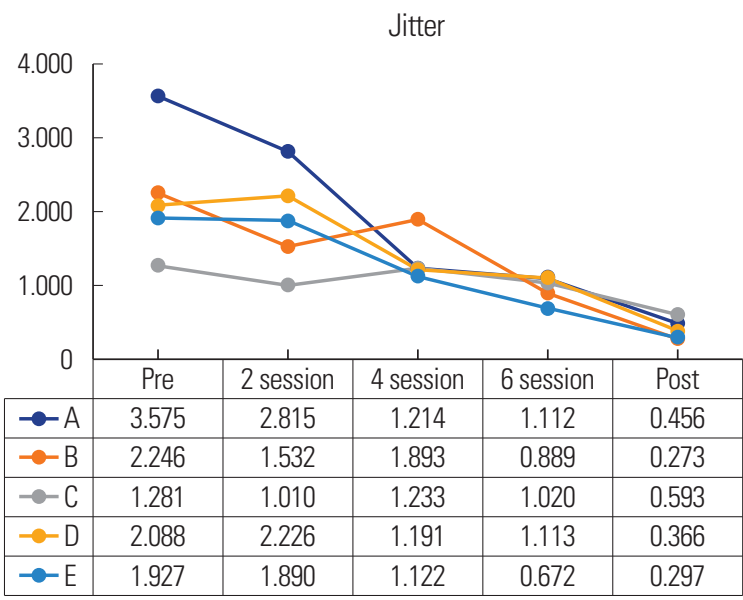

(B)

NHR

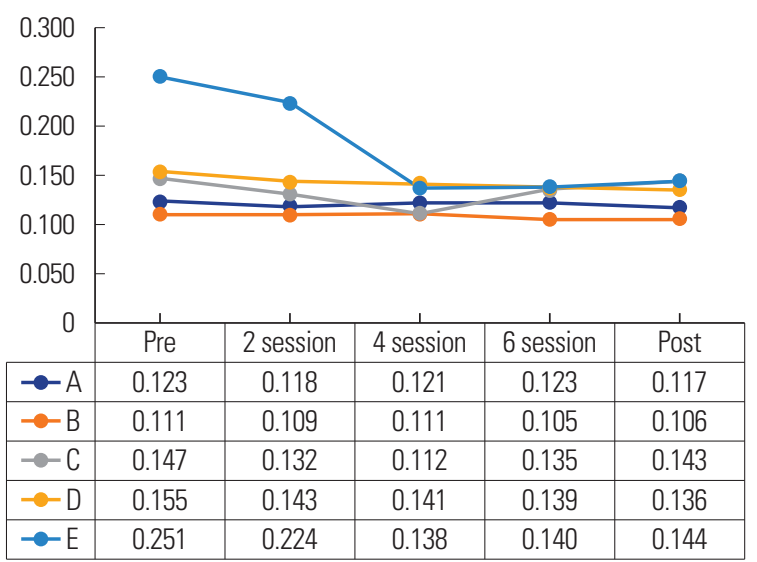

(D)

Figure 5. Result of acoustic evaluation (Multi-Dimensional Voice Program): (A) Fo, (B) jitter, (C) shimmer, and (D) noise-to-harmonic ratio (NHR). 


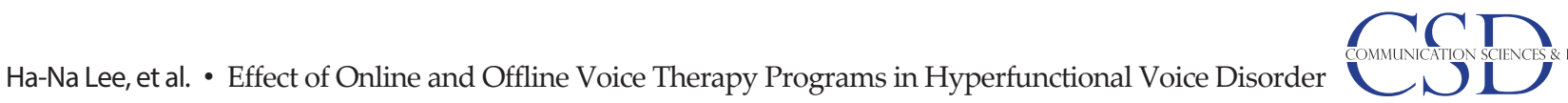

는 반음의 개수가 15 개 증가하였으며, 환자 $\mathrm{B}$ 는 반음(semitone)의 개 수는 동일하였으나 주파수범위 $(\mathrm{Hz})$ 는 치료 전에 비해 향상된 것을

Fo range $(\mathrm{Hz})$

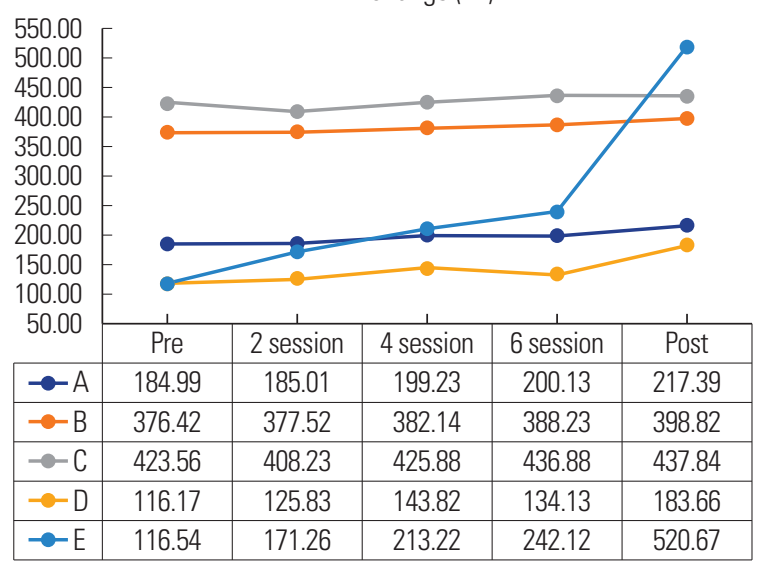

(A)
확인할 수 있었다. 이러한 결과를 보면 치료 후 환자의 음역이 치료 전에 비해 넓어졌음을 알 수 있었다. VRP 결과는 Figure 6과같다.

Figure 6. Result of acoustic evaluation (Voice Range Profile): (A) FO range ( $\mathrm{Hz}$ ) and (B) FO range (semitone).

FVC (L)

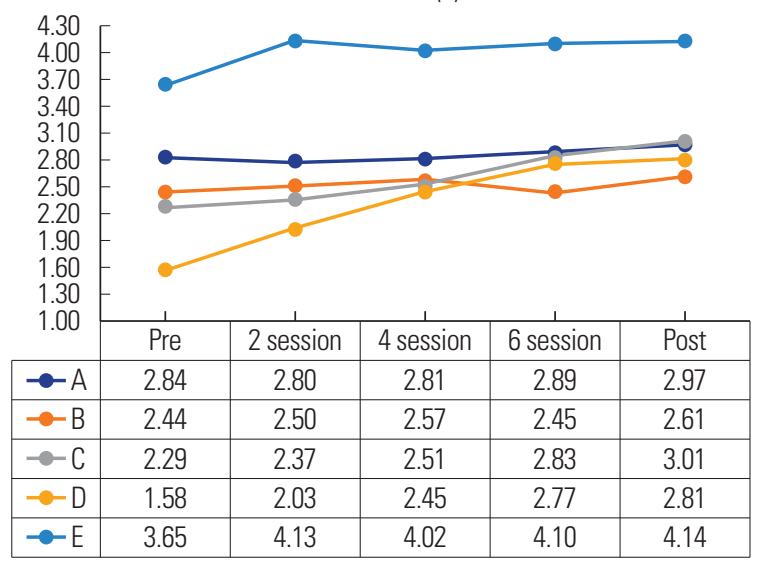

(A)

PHOT (sec)

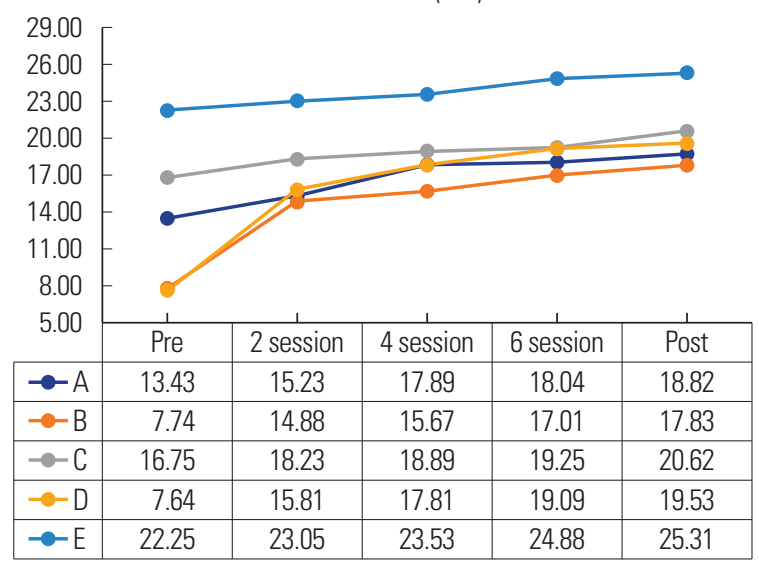

(C)
Fo range (semitone)

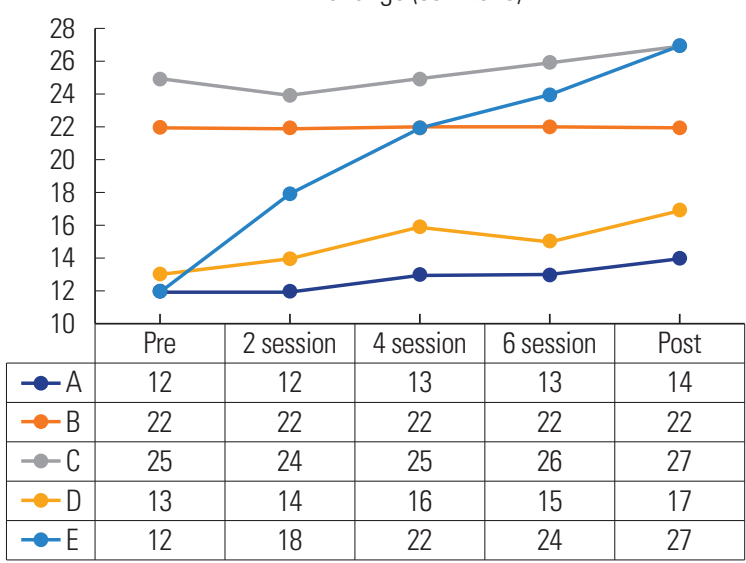

(B)

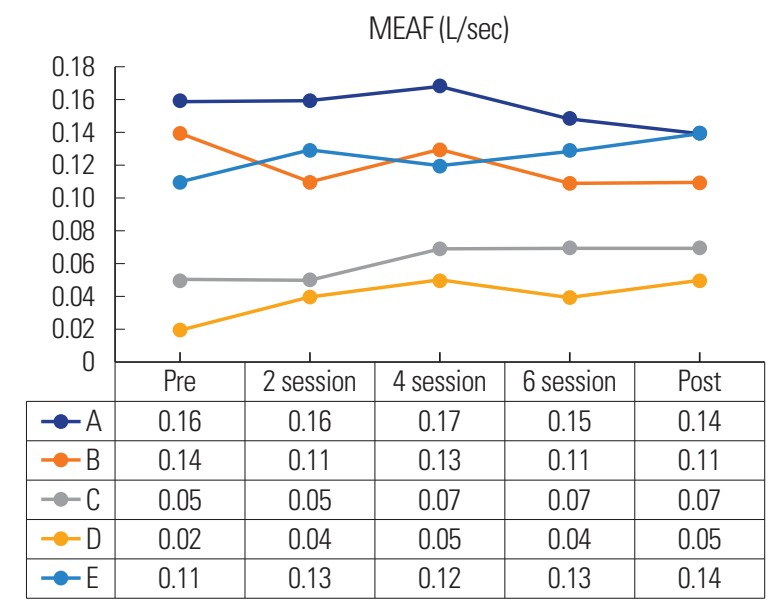

(B)

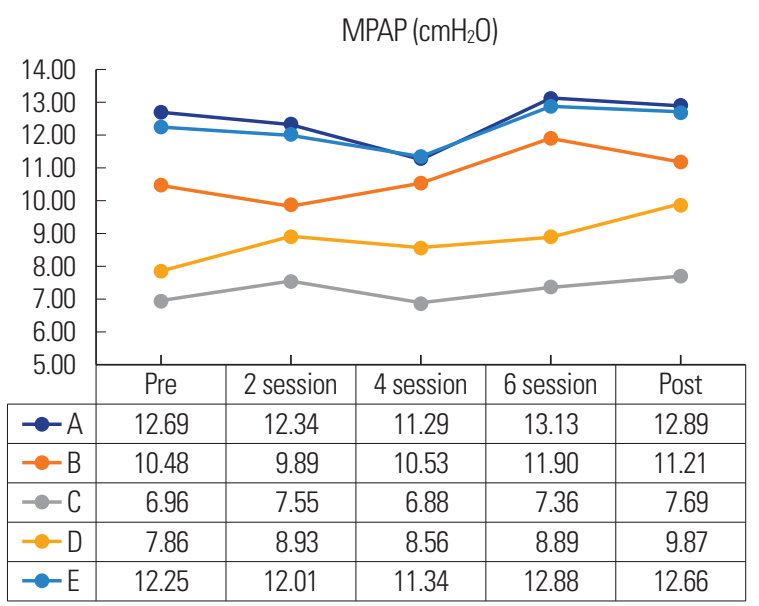

(D)

Figure 7. Result of aerodynamic evaluation (Phonatory Aerodynamic System): (A) expiratory volume (FVC), (B) mean expiratory airflow (MEAF), (C) maximum phonation time (PHOT), and (D) mean air pressure (MPAP). 
Table 4. Result of subjective evaluation (GRBAS)

\begin{tabular}{|c|c|c|c|c|c|c|c|c|c|c|}
\hline \multirow{2}{*}{ Subject } & \multicolumn{2}{|c|}{ G } & \multicolumn{2}{|c|}{ R } & \multicolumn{2}{|c|}{ B } & \multicolumn{2}{|c|}{ A } & \multicolumn{2}{|c|}{$S$} \\
\hline & Pre & Post & Pre & Post & Pre & Post & Pre & Post & Pre & Post \\
\hline$A$ & 3 & 0 & 1 & 0 & 3 & 0 & 3 & 0 & 1 & 0 \\
\hline B & 3 & 0 & 1 & 0 & 3 & 0 & 3 & 0 & 2 & 1 \\
\hline C & 3 & 2 & 3 & 2 & 3 & 2 & 3 & 1 & 2 & 1 \\
\hline$D$ & 3 & 1 & 2 & 1 & 2 & 0 & 3 & 0 & 2 & 1 \\
\hline$E$ & 3 & 0 & 3 & 0 & 2 & 0 & 2 & 0 & 3 & 1 \\
\hline
\end{tabular}

GRBAS scale = grade, roughness, breathiness, asthenia, strain.

Table 5. Result of subjective evaluation (Voice Handicap Index)

\begin{tabular}{|c|c|c|c|c|c|c|c|c|}
\hline \multirow{3}{*}{ Subject } & \multicolumn{8}{|c|}{ Voice Handicap Index } \\
\hline & \multicolumn{2}{|c|}{ Functional } & \multicolumn{2}{|c|}{ Physical } & \multicolumn{2}{|c|}{ Emotional } & \multicolumn{2}{|c|}{ Total } \\
\hline & Pre & Post & Pre & Post & Pre & Post & Pre & Post \\
\hline$A$ & 17 & 0 & 28 & 10 & 14 & 0 & 59 & 10 \\
\hline B & 12 & 1 & 21 & 9 & 15 & 2 & 48 & 12 \\
\hline C & 21 & 5 & 36 & 12 & 17 & 0 & 74 & 17 \\
\hline D & 23 & 4 & 26 & 3 & 31 & 3 & 90 & 10 \\
\hline $\mathrm{E}$ & 20 & 8 & 28 & 12 & 19 & 1 & 67 & 21 \\
\hline
\end{tabular}

\section{공기역학적 음성개선}

PAS

공기역학적인 평가는 PAS를 사용하여 치료 전후 발성과 관련된 호흡기능의 변화를 알아보고자 하였다. PAS 평가 결과, Figure 7과 같이 환자 모두 치료 전에 비해 폐활량(FVC)과 최대연장발성시간 (PHOT)이 증가하였으며 이를 PAS에서 제공하는 각 연령별 정상 수치와 비교했을 때 정상범위에 해당하였다. 이러한 결과는 치료 후 환자의 발성과 관련된 호흡기능이 향상되었음을 알 수 있었다. 반면 성문하압(MPAP)의 경우, 대부분의 환자들에서 약간 증가한 것으로 나타났다. PAS 결과는 Figure 7과같다.

\section{주관적 음성개선}

GRBAS 척도

치료 전후 환자 음성의 청지각적인 평가를 하기 위해 GRBAS 척 도를 실시하였다. GRBAS 평가 결과, 환자 모두 치료 전과 비교하여 $\mathrm{G}, \mathrm{R}, \mathrm{B}, \mathrm{A}, \mathrm{S}$ 등 모든 항목에서 점수가 감소하였다. 환자별 GRBAS 평가 결과는 Table 4 와 같다.

\section{음성장애지수}

치료 전후 주관적 음성 만족도를 평가하기 위해 $\mathrm{VHI}$ 를 실시하 였다. VHI 평가 결과, 치료 전 중도 이상에 음성장애를 호소한 환자 들은 치료 후 일상생활에서 목소리로 인한 불편함을 호소하지 않 는 것으로 나타났다.
따라서 치료 후 환자 모두 주관적인 음성만족도가 증가하였다 라고 할 수 있다. 환자별 음성장애지수 결과는 Table 5 와 같다.

\section{논의 및 결론}

본 연구는 온·오프라인 음성치료 프로그램이 음성장애 환자의 음성개선에 효과적인지 알아보고자 하였다. 음성의 개선 정도는 MDVP, VRP, PAS를 통해 객관적인 음성의 변화를 알아보았고, GRBAS 척도, $\mathrm{VHI}$ 를 통해 주관적 음성의 개선 정도를 알아보았다. 온·오프라인 음성치료 프로그램의 음성개선 효과는 다음과같았다.

첫째, MDVP를 통해 음도와 음질의 변화를 알아본 결과, 치료 후 음도, 음질에서 음성개선이 나타났다. 연구 결과, 환자 $C$ 는 치료 전, 여성을 기준으로 부적절한 음도인 $160.26 \mathrm{~Hz}$ 에서 치료 후 $215.23 \mathrm{~Hz}$ 로 음도가 정상범위에 해당하였고 환자 $\mathrm{D}$ 는 치료 전 음 도가 $219.00 \mathrm{~Hz}$ 로 매우 높았지만, 치료 후 $145.50 \mathrm{~Hz}$ 로 음도가 정상 범위 쪽으로 낮아지는 긍정적인 음도 변화가 나타났다. 환자 $\mathrm{A}, \mathrm{B}, \mathrm{E}$ 는 치료 전에 비해 음도가 증가하였는데 이는 Lim, Kim, Kwon과 Park (2009)의 연구에서 8주간 성대결절 환자에게 총체적 음성치 료방법인 성대기능훈련을 실시한 결과, 기본주파수가 증가한 결과 와 일치하며 음성치료 후 성대병변의 호전과 성대 긴장도 완화로 인해 증가된 것으로 사료된다. 또한 주파수변동률(jitter)과 진폭변 동률(shimmer)은 치료 전보다 감소하였으며 정상범위에 해당하였 고, 소음대배음비(NHR)는 치료 후 모든 환자에서 정상범위로 나 
Ha-Na Lee, et al. • Effect of Online and Offline Voice Therapy Programs in Hyperfunctional Voice Disorder

타났다. 이러한 음질과 음도의 개선은 Yoo와 Lee (2018)의 연구에 서 성대에어로빅치료를 실시한 후, 환자가 본인에게 적합한 음도를 사용하였고 음질적인 측면에서 주파수변동률(jitter), 진폭변동률 (shimmer), 소음대배음비(NHR)가 정상범위에 해당한 결과와 일 치하였다. 또한 Kang과 Yoo (2019)의 연구에서도 성대에어로빅치 료를 실시한 후 환자의 음도, 음질 개선이 나타났다는 결과와 일치 하였다. 따라서 성대에어로빅치료 프로그램은 과기능적 음성장애 환자의 음도와음질개선에 효과적인 것을 알 수 있었다.

둘째, $\mathrm{VRP}$ 를 통해 음역의 변화를 알아본 결과, 치료 후 음역에서 음성개선이 나타났다. VRP 결과 치료 전에 비해 주파수범위 $(\mathrm{Hz})$ 가 증가하였으며, 반음(semitone)의 개수는 동일하거나 증가하였 다. 이는 Yoo와 Lee (2018)의 연구에서 성대에어로빅치료를 실시한 후, 음역적인 측면에서 주파수범위 및 반음의 개수의 향상이 나타 난 결과와 일치하였다. 또한 호흡훈련기를 활용한 성대에어로빅치 료를 실시한 Kang과 Yoo (2019)의 연구에서 치료 후 주파수범위가 증가하였다는 결과와 일치한다. 따라서 성대에어로빅치료 프로그 램은 환자의 음역 증가에 효과적인 것으로 나타났다.

셋째, PAS를 통해 발성과 관련된 호흡기능의 변화를 알아본 결 과, 환자 모두 치료 전에 비해 폐활량(FVC)과 최대연장발성시간 (PHOT)이 증가하였으며 각 연령별 규준치와 비교해 정상범위에 해당하였다. 이러한 결과는 Lim 등(2009)의 연구에서는 성대결절 환자에게 총체적 음성치료방법인 성대기능훈련을 실시한 결과, 최 대연장발성시간(PHOT)에서 유의미한 향상이 있었다는 선행연구 와 일치하였다. 평균호기류율(MEAF)은 치료 전 평균보다 높은 수 치를 보여 발성 시 기식적인 음성을 보이던 환자 $\mathrm{A}$ 와 $\mathrm{B}$ 는 치료 전에 비해 평균호기류율(MEAF)이 감소하였으며 정상범위에 해당하였 다. 이는 온.오프라인 음성치료 프로그램을 통해 습득한 발성방법 을 통해 환자가 발성 시 기류를 덜 빠져나가게 하여 좀 더 효율적으 로 사용하게 되었다는 것을 의미한다. 환자 $\mathrm{C}, \mathrm{D}, \mathrm{E}$ 는 치료 전 발성 시 긴장을 동반하여 기류가 덜 빠져나가는 편이었으나 치료 후 평 균호기류율(MEAF) 수치가 증가하여 발성 시 긴장을 동반하지 않 고 사용한다는 것으로 해석할 수 있다. 반면 성문하압(MPAP)은 환자 모두 치료 전에 비해 증가하였다. 그러나 이러한 수치 변화의 정도가 매우 작은 편이라 치료 전후의 성문하압(MPAP) 변화를 수 치로 설명하기는 다소 어려운 점이 있다. 치료 후, 성문하압(MPAP) 이 정상 규준치보다 높은 것은 호흡훈련을 통해 호기력이 증가한 것일 수도 있으며, 아직까지 목에 약간 힘을 주어 발성하는 습관이 남아 있는 것과 관련이 있을 수 있다고 판단된다.

넷째, 주관적 평가 중 청지각적 평가인 GRBAS 평가 결과 환자 모 두 치료 전과 비교하여 전체적인 목쉰 소리(Grade), 거친 소리
(Rough), 기식적 소리(Breathy), 무력한 소리(Asthenic), 쥐어짜는 소리(Strain) 등의 모든 항목에서 점수가 감소하였다. 이는 Kim 등 (2009)의 연구에서 성대용종 환자를 대상으로 음성치료를 실시한 결과 ' $G$ ', 'R', 'B'에서 점수가 유의하게 감소한 결과와 일치하였다. 또한 과기능적 음성장애 환자에게 후두마사지와 반폐쇄성도훈련 을 실시한 연구에서도 치료 후 'G', 'R', 'B'에서 유의한 개선이 나타 났다는 결과와 일치하였다(Kim, Lee, Choi, \& Choi, 2017). 따라서 온·오프라인 음성치료 프로그램은 청지각적 음성개선에 효과적이 라고 할수 있다

다섯째, 자기보고식 음성평가 결과 음성장애지수의 총점과 신체 적, 기능적, 정서적 영역의 점수가 치료 전과 비교하여 감소하였으 며 정상수준에 해당하였다. 이는 환자가 주관적으로 느끼는 음성 장애의 정도가 감소된 것으로 해석할 수 있으며 실제 환자들은 음 성치료 후 일상생활에서 목소리로 인한 불편함을 호소하지 않았 다. 또한 환자들은 본인 음성에 대한 만족도가 향상되었음을 보고 하였다. 이러한 결과는 Pedrosa, Pontes, Pontes, Behlau와 Peccin (2016) 연구에서 음성재활 프로그램과 성대기능훈련을 사용한 음 성치료 후 음성장애지수가 감소하여 음성이 개선된 결과와 일치하 였다. 또한 Park 등(2000)의 연구에서는 성대결절 및 후두폴립 수 술을 실시한 환자에게 악센트 기법을 실시한 결과, 주관적인 음성 만족도에서도 향상이 나타났다는 결과와도 일치하였다.

본 연구에서는 온·오프라인 음성치료 프로그램이 과기능적 음 성장애 환자의 음성개선에 효과적인지 알아보고자 사례연구를 실 시하였다. 연구 결과 음도, 음질, 음역에서 음성의 개선이 나타났으 며 발성과 관련된 전반적인 호흡능력에 향상에 효과적인 것으로 나 타났다. 또한 청지각적 음성평가에서 음성의 개선이 나타났으며, 자 기보고식 음성평가에서 주관적인 음성만족도가 증가하였다. 이러 한 결과를 토대로 온·오프라인 음성치료 프로그램은 과기능적 음 성장애 환자의 음성개선에 효과적인 것으로 나타났다. 본 연구에 대한 논의 및 제언은 다음과 같았다.

첫째, 국내연구에서 온·오프라인을 병행한 음성치료 프로그램 의 효과성을 알아본 연구는 거의 없었으나 본 연구에서는 온.오프 라인 음성치료 프로그램의 효과성에 대해 알아보았다는 점에서 연 구 의의가 있었다. 선행연구에서 다양한 디지털 매체를 활용한 음 성치료 및 평가, 원격치료(telepractice)의 효과성에 대해 보고되고 있었다(Cole et al., 2007; Lee et al., 2018; Lee et al., 2019; Mashima et al., 2003; Rangarathnam et al., 2015). 그러나 국내에서는 다양한 디지털 매체를 활용한 음성치료 효과성에 대해 알아본 연구가 부 족한 실정이었다. 본 연구 결과에서 온·오프라인 음성치료 프로그 램이 과기능적 음성장애 환자의 음성개선에 효과적이라는 결과는 
다양한 디지털 매체를 활용한 음성치료 효과에 대한 연구의 필요 성을 뒷받침할 수 있는 연구라고 할수 있다.

따라서 향후 연구에서는 다양한 IT기술과 음성치료를 접목시킨 음성치료 효과성에 대한 연구가 활발히 진행되길 기대한다. 나아가 전통적인 면대면 음성치료뿐만 아니라 원격치료의 유용성에 대한 연구가 진행되어야 할 필요가 있다.

둘째, 본 연구에서는 환자가 치료실뿐만 아니라 가정에서 연습할 수 있는 온라인기반 음성치료 프로그램의 적용 가능성과 개발의 필요성을 확인하였다. 본 연구는 가정에서 환자의 지속적인 연습 을 독려하기 위해 스마트폰기반 온라인 음성치료 프로그램을 실시 하였다. 연구에 참여한 환자들은 온라인 음성치료 프로그램에 긍 정적인 반응을 보였으며, 온라인 음성치료 프로그램에 사용된 홈 보이스 트레이너의 기능 중 음성에 대한 시청각 피드백, 음성치료 방법에 대한 동영상 등이 연습을 지속적으로 하는 데 도움이 되었 다고 하였다. 따라서 추후 연구에서는 가정에서 훈련을 독려하기 위한 다양한 음성치료 콘텐츠 개발 연구가 필요하며, 과기능적 음 성장애 환자뿐만 아니라 다양한 유형의 음성장애 환자를 위한 음 성치료 콘텐츠 개발을 위한 연구가 지속적으로 이루어질 필요가 있다.

셋째, 본 연구에서는 온·오프라인 음성치료 프로그램을 과기능 적 음성장애 환자에게 적용한 사례연구로 다양한 음성장애 환자 집단, 많은 수의 환자를 대상으로 프로그램을 적용하지 못한 한계 점이 있었다. 따라서 차후 연구에서는 온.오프라인 음성치료 프로 그램의 효과성을 검증하기 위해 다양한 음성장애 유형과 더 많은 수의 음성장애 환자를 대상으로 적용한 치료의 효과성에 대한 연 구가 이루어져야 할 것이다. 또한 음성장애 유형별 온.오프라인 회 기수의 적절성, 종결 후 유지 효과에 대한 연구가 후속연구로 이어 져야할 것이다.

마지막으로 본 연구는 온·오프라인 음성치료 프로그램의 적용 가능성에 대해 알아보았으며 향후 연구에서는 임상에서 사용되는 근거기반 음성치료법의 온라인 프로그램 개발 및 적용 연구가 활발 히 이루어지길 기대한다.

\section{REFERENCES}

Ahn, C. M., Shin, I. S., \& Shin, J. E. (2016). The study of satisfaction of voice therapy in patients with voice disorders. Journal of the Korean Society of Laryngology, Phoniatrics and Logopedics, 27(1), 35-39.

Bae, I., Park, H., Kim, G., \& Kwon, S. B. (2014). Development of the augmented reality based speech language therapy program. Journal of Speech-
Language and Hearing Disorders, 23(2), 139-152.

Choi, S. H. (2013). Speech-language pathologists' voice assessment and voice therapy practices: a survey for standard clinical guideline and evidencebased practice. Communication Sciences \& Disorders, 18(4), 473-485.

Cole, R., van Vuuren, S., Ngampatipatpong, N., Halpern, A., Ramig, L., \& Yan, J. (2007). A virtual speech therapist for individuals with Parkinson's disease. Educational Technology, 47(1), 51-56.

Fu, S., Theodoros, D. G., \& Ward, E. C. (2015). Delivery of intensive voice therapy for vocal fold nodules via telepractice: a pilot feasibility and efficacy study. Journal of Voice, 29(6), 696-706.

Grillo, E. U. (2017). An online telepractice model for the prevention of voice disorders in vocally healthy student teachers evaluated by a smartphone application. Perspectives of the ASHA Special Interest Groups, 2(3), 63-78.

Howell, S., Tripoliti, E., \& Pring, T. (2009). Delivering the Lee Silverman Voice Treatment (LSVT) by web camera: a feasibility study. International Journal of Language \& Communication Disorders, 44(3), 287-300.

Kang, H. N., \& Yoo, J. Y. (2019). A case study of the effects of respiration trainers on vocal aerobic treatment program. Communication Sciences \& Disorders, 24(1), 244-260.

Kim, J. H. (2018). Smartphone-based vocal function exercises and a voice quality evaluation application for patients with vocal nodules (Master's thesis). Soonchunhyang University, Asan, Korea.

Kim, J. S., Lee, D. W., Choi, C. H., \& Choi, S. H. (2017). Effects of laryngeal massage and semi-occluded vocal tract exercises for patients with hyperfunctional dysphonia. Communication Sciences \& Disorders, 22(4), 806817.

Kim, S. T., Jeong, G. E., Kim, S. Y., Choi, S. H., Lim, G. C., Han, J. H., \& Nam, S. Y. (2009). The effect of voice therapy in vocal polyp patients. Phonetics and Speech Sciences, 1(2), 43-49.

Lee, H. N., Park, J. H., \& Yoo, J. Y. (2019). Development of smartphone-based voice therapy program. Phonetics and Speech Sciences, 11(1), 51-61.

Lee, S. J., Lee, K. Y., \& Choi, H. S. (2018). Clinical usefulness of voice recordings using a smartphone as a screening tool for voice disorders. Communication Sciences \& Disorders, 23(4), 1065-1077.

Lim, H. J., Kim, J. K., Kwon, D. H., \& Park, J. Y. (2009). The effect of vocal function exercise on voice improvement in patients with vocal nodules. Phonetics and Speech Sciences, 1(2), 37-42.

Mashima, P. A., Birkmire-Peters, D. P., Syms, M. J., Holtel, M. R., Burgess, L., \& Peters, L. J. (2003). Telehealth: voice therapy using telecommunications technology. American Journal of Speech-Language Pathology, 12(4), 432- 
439.

Park, H. J., Kim, G. H., Lee, Y. W., Bae I. H., \& Kwon, S. B. (2019) Development and application of augment reality based voice therapy software. Proceedings of the Korean Society of Speech Sciences Spring Conference.

Park, H. S., Park, Y. S., Choi, D. Y., Kim, S. Y., Yoo, S. J., \& Nam, S. Y. (2000)

The utility of accent method as a supplementary treatment after surgery of vocal nodule and laryngeal polyp. Journal of the Korean Society of Laryngology, Phoniatrics and Logopedics, 11(1), 39-45.

Pedrosa, V., Pontes, A., Pontes, P., Behlau, M., \& Peccin, S. M. (2016). The effectiveness of the comprehensive voice rehabilitation program compared with the vocal function exercises method in behavioral dysphonia: a randomized clinical trial. Journal of Voice, 30(3), 377.e11-377.e19.

Rangarathnam, B., McCullough, G. H., Pickett, H., Zraick, R. I., Tulunay-
Ugur, O., \& McCullough, K. C. (2015). Telepractice versus in-person delivery of voice therapy for primary muscle tension dysphonia. American Journal of Speech-Language Pathology, 24(3), 386-399.

Tindall, L. R., Huebner, R. A., Stemple, J. C., \& Kleinert, H. L. (2008). Videophone-delivered voice therapy: a comparative analysis of outcomes to traditional delivery for adults with Parkinson's disease. Telemedicine and eHealth, 14(10), 1070-1077.

Yoo, J. Y., \& Lee, H. N. (2018). A case study on vocal aerobic treatment voice therapy development and application for classical singers. Journal of Rehabilitation Research, 22(1), 157-168.

Yun, Y. S., Kim, H., Son, Y. I., \& Choi, H. S. (2008). Validation of the Korean Voice Handicap Index (K-VHI) and the clinical usefulness of Korean VHI-10. Korean Journal of Communication \& Disorders, 13(2), 216-241. 


\section{국문초록}

\section{온·오프라인 음성치료 프로그램이 과기능적 음성장애 환자의 음성개선에 미치는 효과: 사례연구 이하나 ${ }^{1}$ 유재연 ${ }^{2} \cdot$ 박준희 ${ }^{3}$ \\ '조선대학교병원 이비인후과 음성클리닉, ${ }^{2}$ 호남대학교 언어치료학과, ${ }^{3}$ 조선대학교 의과대학 이비인후과학교실}

배경 및 목적: 음성치료는 음성산출행동을 바꾸어 더 나은 음성을 산출하는 것을 목표로 한다. 따라서 일상생활에서 환자의 꾸준한 연습과 행동 변화가 요구된다. 스마트폰을 활용한 음성치료는 일상생활에서의 음성훈련을 독려할 뿐만 아니라 훈련 시 음성에 관한 객 관적인 자료 제공이 가능하다. 본 연구에서는 스마트폰을 활용한 온·오프라인 음성치료 프로그램이 음성장애 환자의 음성개선에 효과 적인지 알아보고자 하였다. 방법: 연구는 과기능적 음성장애를 가진 5명을 대상으로 실시하였다. 음성치료는 Vocal Aerobic Treatment 를 기반으로 실시하였으며, 주 1 회의 오프라인 음성치료 프로그램과 주 1 회 이상 온라인 음성치료 프로그램을 실시하였다. 음성평가는 치료 전후로 음향학적 평가(MDVP, VRP), 공기역학적 평가(PAS), 주관적 음성평가(GRBAS, VHI)를 실시하였다. 결과: 음향학적 평가 결과 치료 후 주파수변동률(jitter), 진폭변동률(shimmer), 소음대배음비(NHR)가 감소하였으며 주파수범위(Hz)와 반음(semitone)의 개수가 증가하였다. 공기역학적 평가결과 폐활량 $(\mathrm{FVC})$, 최대연장발성시간 $(\mathrm{PHOT})$ 이 증가하였으며 발성과 관련된 호흡기능의 향상이 나타났다. 주관적 음성평가 결과, 음성장애의 정도가 치료 전에 비해 감소된 것으로 나타났다. 논의 및 결론: 온·오프라인 음성치료 프 로그램은 음성장애 환자의 음도와 음질개선, 음역 증가, 발성과 관련된 호흡기능의 향상에 효과적인 것으로 나타났다. 차후 연구에서는 다양한 환자를 대상으로 온·오프라인 음성치료 프로그램의 효과성에 대한 연구가 필요하다. 또한 근거기반 임상에 활용되는 음성치료 기법의 온라인 프로그램 개발 및 적용 연구가 활발히 이루어질 필요가 있다.

핵심어: 홈 보이스 트레이너, 온라인 음성치료, 성대에어로빅치료, 음성치료, 음성장애

\section{참고문헌}

강하늘, 유재연(2019). 호흡훈련기를 활용한 성대에어로빅치료 프로그램의 음성개선 효과 사례연구. Communication Sciences \& Disorders, 24(1), 244-260.

김성태, 정고은, 김상윤, 최승호, 임길채, 한주희, 남순열(2009). 성대용종 환자의 음성치료 효과. 말소리와음성과학, 1(2), 43-49. 김지성, 이동욱, 최철희, 최성희(2017). 후두마사지와 반폐쇄성도훈련이 과기능적 음성장애 환자의 음성개선에 미치는 효과. Communication Sciences \& Disorders, 22(4), 806-817.

김지현(2018). 성대 결절 환자를 위한 스마트폰 기반의 음성 기능 훈련 및 음질 평가 애플리케이션. 순천향대학교 일반대학원, 석사학위논문.

박혜성, 박영실, 최두영, 김상윤, 유승주, 남순열(2000). 성대 결절 및 후두 폴립의 수술 후 보충 치료로서 Accent Method의 유용성. 대한후두음성언 어의학회지, 11(1), 39-45.

박희준, 김근효, 이연우, 배인호, 권순복(2019). 증강현실 기반 음성치료 소프트웨어의 개발 및 적용. 한국음성학회 봄 학술대회 논문집. 배인호, 박희준, 김근효, 권순복(2014). 증강현실기반 언어치료 프로그램의 교육적 적용. 언어치료연구, 23(2), 139-152.

안철민, 신익서, 신정은(2016) 음성장애환자의 음성치료 후 만족도 연구. 대한후두음성언어의학회지, 27(1), 35-39.

유재연, 이하나(2018). 성악가를 위한 VAT 음성치료 개발 및 적용 사례연구. 재활복지, 22(1), 157-168.

윤영선, 김향희, 손영익, 최홍식(2008). 한국어판 음성장애지수(Voice Handicap Index, VHI)의 타당도 및 VHI-10의 임상적 유용성. 언어청각장애연 구, 13(2), 216-241.

이승진, 이광용, 최홍식(2018). 음성장애 선별검사 도구로서 스마트폰을 이용한 음성 녹음의 임상적 유용성. Communication Sciences \& Disorders, 23(4), 1065-1077.

이하나, 박준희, 유재연(2019). 스마트폰기반 음성치료 프로그램 개발연구. 말소리와음성과학, 11(1), 51-61. 
Ha-Na Lee, et al. • Effect of Online and Offline Voice Therapy Programs in Hyperfunctional Voice Disorder

임혜진, 김정규, 권도하, 박준영(2009). 성대기능훈련이 성대결절 환자의 음성개선에 미치는 효과. 말소리와음성과학, 1(2), 37-42.

최성희(2013). 음성언어재활사의 음성평가와 음성치료의 임상실제: 표준 임상지침과 증거기반중재를 위한 설문조사. Communication Sciences \&

Disorders, 18(4), 473-485.

\section{ORCID}

이하나(https://orcid.org/0000-0003-4476-1250); 유재연(https://orcid.org/0000-0001-5575-1280); 박준희(https://orcid.org/0000-0001-9335-3443) 